\title{
Guoxue/National Learning in the Age of Global Modernity
}

\section{Arif Dirlik}

\section{(2) OpenEdition \\ 12 Journals}

Electronic version

URL: http://journals.openedition.org/chinaperspectives/5371

DOI: 10.4000/chinaperspectives. 5371

ISSN: 1996-4617

\section{Publisher}

Centre d'étude français sur la Chine contemporaine

\section{Printed version}

Date of publication: 1 January 2011

Number of pages: 4-13

ISSN: 2070-3449

\section{Electronic reference}

Arif Dirlik, « Guoxue/National Learning in the Age of Global Modernity », China Perspectives [Online], 2011/1 | 2011, Online since 30 March 2011, connection on 28 October 2019. URL : http:// journals.openedition.org/chinaperspectives/5371; DOI : 10.4000/chinaperspectives.5371 


\section{Guoxue/National Learning}

\section{in the Age of Global Modernity}

ARIF DIRLIK*

ABSTRACT: Guoxue as an idea and intellectual pursuit has a history of roughly a century in China. From its origins in the last decade of the Qing dynasty (1644-1911), it has been integral to the search for a past that is appropriate to the formation of China as a nation. At the same time, its constitution over time has varied with changing conceptions of the nation, as well as its place in the world. ${ }^{(1)}$ Interest in guoxue declined during the height of the revolution, from the 1940s through the 1960s, but has enjoyed resurgence since the 1990s among scholars and the general public alike. This time around, it expresses a newfound pride in the past that has accompanied success in development, as well as an urge to bring inherited cultural legacies and modes of scholarship into a global dialogue on culture. While very much rooted in the history of modern China, it also parallels in this new phase a reassertion globally of traditions suppressed under the regime of Euromodernity. Its content remains vague, however, and subject to contention from different ideological perspectives.

KEYWORDS: guoxue, kokugaku, national learning, global modernity, nativism, cosmopolitanism, ethno-epistemology, ruxue, Confucianism

$\mathrm{T}$ his discussion will undertake two tasks. The first task is to place guoxue (national learning) within a contemporary global perspective, to suggest that while guoxue may be unique in the nationally defined epistemological territory (a "Chinese" way of knowing) it claims, its claims to epistemological particularism are anything but unique. Epistemological nativism, or a general valorisation of ethnoepistemology, is a pervasive (if not defining) characteristic of contemporary global modernity.

The second task follows from this first one: what are the implications for guoxue as a subject and method of its contemporary global context? While epistemological nativism may be a necessary step in the recovery of epistemologies erased by the universalistic claims of Euromodern ways of knowing, it needs to resist reduction to a parochial marker of national identity in a narrow, ahistorical nationalism. The articulation to other knowledges is necessary if guoxue is to be of epistemological significance beyond national boundaries, to contribute to broader human causes, and, ironically, to enable a more comprehensive understanding of the national past than through a narrow nationalism. Throughout the discussion, I will use guoxue rather than "national learning," as I think the Chinese term guo suggests both more and less than the English term national, a distinction that may be necessary to grasping different understandings of guoxue even among its practitioners.

\section{Global modernity and the proliferation of knowledges}

Simply put, global modernity is modernity globalised. The consequences, however, are anything but global unification or global homogenisation. The political economic integration of the globe, which is usually what is understood by globalisation, has been accompanied by new fragmentations as well as the intensification of earlier ones. If I may cite a passage from a recent work of mine,
The globalization of modernity needs to be comprehended not just in the trivial sense of an originary modernity reaching out and touching all, even those who are left out of its benefits... but more importantly as the proliferation of claims on modernity. So-called traditions no longer imply a contrast with modernity, as they did in modernization discourse. Nor are they the domain of backwardlooking conservatism, except in exceptional circumstances - such as the Taliban. They are invoked increasingly to establish claims to alternative modernities (but only rarely to alternatives to modernity). They point not to the past but, taking a detour through the past, to an alternative future. They have even taken over from socialism the task of speaking for those oppressed or cast aside by capitalist modernity and pointing to different possibilities for the future. (2)

At its paradigmatic simplest, modernisation discourse rendered the modernity/ tradition binary into a zero-sum relationship: the more modernity, the less tradition; the more tradition, the less modernity. Modernity was understood in its Euro/American manifestations (or what I think is best described as Euromodernity): scientific/technological development, a sense of history driven by its commitment to progress, the political institutions associated with parliamentary democracy, and the social primacy of the individual. Except for the last item, socialist modernity shared in these basic assumptions of capitalist modernity. Modernisation, understood as development towards these characteristics, would relegate tradi-

Arif Dirlik lives in semi-retirement in Eugene, OR, USA. He was most recently the first Liang Qichao Memorial Distinguished Visiting Professor at Tsinghua University, Beijing.

1. Several colleagues and friends have been kind enough to read the ms. I am grateful to Samuel Cheung, Victor Mair, John Makeham, Roxann Prazniak, and Wang Hui for their comments and encouragement, while absolving them of any responsibility for the views put forward here.

2. Arif Dirlik (阿里夫・德里克), Global Modernity: Modernity in the Age of Global Capitalism, Boulder, CO, Paradigm Press, 2007, pp. 90-91. Slightly modified from the original. 


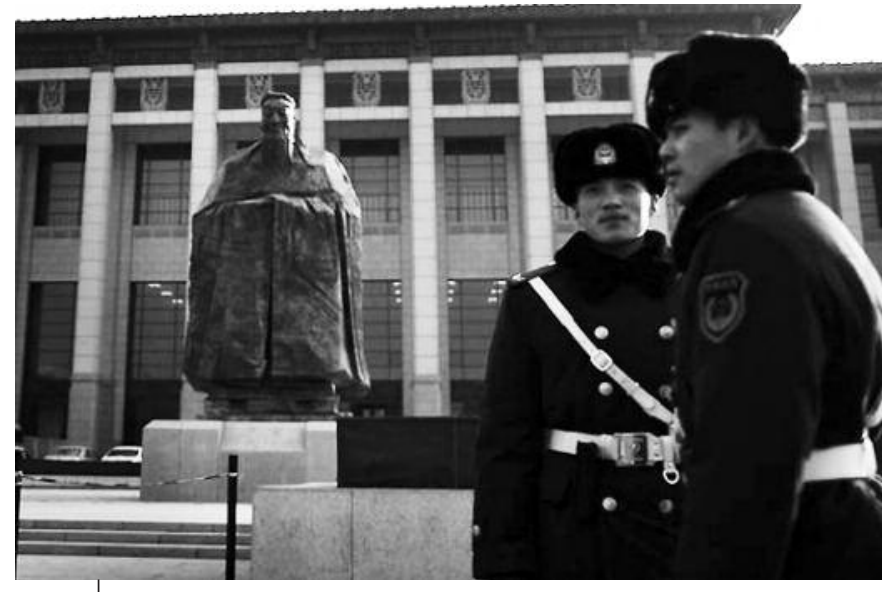

The New Confucius Statue in Tiananmen Square (2011). () Arif Dirlik

tions to the past and, ultimately, to oblivion. Indeed, its logical conclusion was that traditions themselves were inventions of modernity, not false but primarily ideological in substance. Euromodernity, universalised as Modernity as such, was all there was. (3)

Nevertheless, invented or not, the traditions refused to disappear. Those who spoke for traditions were labelled conservatives, which in these cases referred not just to a political (as in nineteenth century Europe) but also to a cultural phenomenon; indeed there was some puzzlement that socalled "cultural conservatives" (defenders of some native tradition or other, and therefore obstacles to urgent tasks of "westernisation," confounded more often than not with modernisation) could on occasion espouse revolutionary politics. The questionable assumptions of these labels aside, there were fundamental reasons, beyond conservative persistence, why the traditions refused to disappear. Traditions, no less the invented than the inherited, were crucial to the formulation of a national identity in the process of nation-building, which was a cornerstone of modernisation. How to deploy traditions in the definition of national identity was a problem that faced all nation-building efforts, regardless of political inclination. The idea of tradition was burdened with a deep contradiction in a modernity premised on nationalism.

This aspect of the problem became evident in the 1960s, the decade of national liberation movements, when notes of nativism began to pervade voices from the political left. It is interesting, if not ironic, that the radical left challenge should transform the terrain of discourse, which in the long run would be of benefit to conservative causes as well in its questioning of the hegemonic dismissal of value systems other than those of Euromodernity. In this case the problem was stated explicitly as the necessity of challenging the ideologies of Eurocentrism as part of the struggle against imperialism. These voices sometimes found legitimation in "alternative traditions" - traditions of the people rather than the elite, as with the conservatives. They sometimes invested the process of struggle itself with the task of creating the traditions necessary to overcome imperialist hegemony and establish a national identity. ${ }^{(4)}$ But even where they had no intention of promoting the traditions espoused by conservatives, radical struggles against hegemony opened up intellectual spaces to legitimation and revival of ideologies, traditions, and knowledges that had been erased or marginalised in Euromodern discourse. This development is plainly visi- ble in the critiques of modernity, questionings of the European Enlightenment, controversies over "Orientalism" that gave rise to postcolonial criticism, the challenges to the disciplinary organisation of knowledge, and the valorisation of new kinds of knowledges that challenged the domination of science. ${ }^{(5)}$ It is easily forgotten these days, because of the turn they took after the 1980s, that these critiques of Euromodernity were products of the 1960s, when Euro/American modernity appeared as the incubator of imperialism, and Third World liberation movements offered alternatives beyond the existing Cold War capitalism/ socialism binary.

The failure (or defeat) of these political movements in the course of the 1970s did not extinguish their cultural promise, but rephrased them increasingly as if they were issues in cultural debate rather than in the practise of revolution, erasing important class issues in the shaping of cultural relationships, and blurring the boundaries between elite culture and national culture in general. At the same time, more conventional "conservatisms" acquired renewed prestige due to the roles they played in the political and/or economic success of several societies. Of particular importance were the Islamic revival that attended the success of the Iranian Revolution of 1979, and the Confucian revival during the very same period that benefited from the developmental success of authoritarian East Asian societies that claimed cultural legacies for their success. It seems in hindsight that over the decade of the 1970s, cultural nationalism came to replace the idea of national liberation, which was not just cultural, or most importantly so. Further impetus to the so-called "cultural turn" came from the resurgence of religious politics in the homelands of Euromodernity, particularly in the USA.

At the same time, the global left was transformed in the process of accommodating new social voices, especially ethnic and national voices, which increased the possibilities of a left accommodation of previously conservative positions. As biologically inflected identity markers have moved to the foreground of discourse (such as race, ethnicity, gender, and even culture understood with reference to them), social categories such as class have nearly disappeared from the language of politics. Multi-culturalism makes it very difficult to repudiate any cultural claim on political grounds. Left positionings have been confounded by the languages of postmodernity and, subsequently, postcolonialism, which acquired currency in the 1990s, at the same time as globalisation. While intensely sensitive to issues of hegemony, postcolonial criticism relegates those issues to the cultural realm, replacing the conquest of imperialism with the conquest of Eurocentrism or Orientalism.

As culture increasingly became a force that shaped political alignments in the 1980s, it also contributed to a gradual blurring of the categories of an earlier political language, especially its classification of political positions around a progressive conservative-liberal-radical continuum, which had been premised on earlier assumptions of cultural progress and mod-

3. For classic critiques of modernisation discourse, see, Dean Tipps, "Modernization Theory and the Comparative Study of Societies: A Critical Perspective," Comparative Studies in Society and History, no. 15, March 1973, pp. 199-226, and, Carl Pletsch, "The Three Worlds, or the Division of Social Scientific Labor, Circa 1950-1975," Comparative Studies in Society and History, no. 23, October 1981, pp. 565590. See also Eric Hobsbawm and Terence Ranger, The Invention of Tradition, Cambridge, UK, Cambridge University Press, 1992.

4. For a discussion of revolutionary theorists ranging from Mao Zedong to Frantz Fanon, see Arif Dirlik, "Culturalism as Hegemonic Ideology and Liberating Practice," in Arif Dirlik, The Postcolonial Aura: Third World Criticism in the Age of Global Capitalism, Boulder, CO, Westview Press, 1997, pp. 23-51.

5. Arif Dirlik, "Our Ways of Knowing: Clobalization - the End of Universalism?", in Petra Rethmann, Imre Szeman and William D. Coleman (ed.), Cultural Autonomy: Frictions and Connections, Vancouver, BC, University of British Columbia Press, 2009. 
ernisation. Indeed, as the Enlightenment vision that underlay Euromodernity came under question from the inside (neoliberal critics of secular humanism) and the outside (postcolonial societies that had experienced the Enlightenment as colonisation), the result was the confounding of the very temporalities that had endowed these terms with meaning.

If "global multiculturalism" has been one product of these changes, its antinomy has been the "Clash of Civilisations." Samuel Huntington's 1993 essay was informed by a sense of the disintegration of modernity (what I am calling Euromodernity). The "civilisations" that now challenged "Western" dominance were products of distant but not bygone pasts. They were modern, and it was their success in modernity that now empowered their claims on tradition (or cultural identity). The clash was between modern societies, each with its own vision of modernity defined in terms of civilisational pasts. The question this situation presents is how to explain the dynamics and significance of the simultaneous globalisation of modernity (capitalist modernity) and the proliferating claims to uniqueness and "difference" it generates. It may be the ultimate question of what we have come to describe as post-modernity, which I consider one aspect of a broader global modernity.

\section{Legacies}

The global context is indispensable to grasping the revival of guoxue since the 1990s, as well as the new challenges it faces as an intellectual undertaking. It is interesting that the first formal calls for the revival of guoxue in 1993 coincided with the publication of Samuel Huntington's notorious "clash of civilisations" article. These calls were preceded, however, by the Confucian revival among Chinese societies overseas, which had already had an impact on the PRC in the mid-1980s, and may have been one of the inspirations behind Huntington's article.

Questions concerning guoxue cannot be understood simply in terms of the structural conditions of global modernity. While China's placement in global developments provides an indispensable perspective for contemporary readings of guoxue, equally indispensable is the perspective of the century-long development of guoxue, with all its ups and downs, which continues to condition both its intellectual substance and the ideological expectations invested in it.

In a cogent analysis of guoxue written in the late 1990s, Cheng Gang (程鋼) and Cao Li (曹莉) draw on the work of scholars such as Chen Lai (陳來) and Chen Pingyuan (陳平原), guoxue advocates who were at the time professors at Peking University, to suggest that the trajectory of guoxue as a field of learning has been shaped by the dynamic interplay of two paradigms still apparent in differences among contemporary scholars in the understanding of guoxue, and in the intellectual, cultural, and political functions associated with it. ${ }^{(6)}$ One paradigm, which may be described as "nativist," is traceable to late Qing/ early Republican scholarship, of which the foremost representative was the distinguished classical scholar Zhang Taiyan (章太炎, 1869-1936). ${ }^{(7)}$ This paradigm renders guoxue into a means of identifying, and even representing a Chinese essence, or the national character; guoxue provides at once the locus of national identity and a method for its analysis. The other, "cosmopolitan," paradigm, was a product of the May Fourth New Culture Movement (新文化運動, xin wenhua yundong), which in its basic assumptions negated the nativist paradigm. It was enunciated most explicitly by the liberal intellectual $\mathrm{Hu}$ Shi (胡适, 1891-1962), at the time a professor at Peking University, who sought to establish guoxue as the critical study of the national past through the investigative technologies of Euromodernity; guoxue is understood in this case as national studies informed by modern methods, with the past as its object. ${ }^{\left({ }^{8}\right)}$ The past as subject, speaking to the present, versus the past as the suspect (疑古, yigu) object of present interrogation may be the most important distinguishing feature of the two paradigms. It is probably safe to say that no reputable guoxue advocate believed that the past should or could be restored, or placed it beyond question; after all, questioning the past had long been a driving force of imperial scholarship, of which Zhang Taiyan was a foremost representative. But adherents of the two paradigms held radically different views on whether or not the past had anything positive to contribute to the present.

The recognition of two such paradigms at odds with one another is revealing of a broad understanding of guoxue that ranges from a belief in its significance for perpetuating a national essence that is crucial to national existence and well-being, to one that seeks to supply it with Euromodern tools to eradicate and rewrite the past that produced that essence, because it had become an obstacle to national progress. And over its century-long existence, guoxue has gone through phases resulting from the interplay of these two paradigms. It was indeed the nativism accompanying emergent national consciousness that gave rise to guoxue in the first place, and guoxue has experienced a revival with every resurgence of nativism. The cosmopolitan paradigm enjoyed its greatest appeal in the 1920s, following the New Culture Movement, itself an attack on inherited culture and a call to its transformation. Guoxue in the 1920s appeared in a number of guises that reflected the tensions created by the conflict of paradigms, but clearly with cosmopolitanism setting the agenda. The 1930s under the Kuomintang government (conservative but with revolutionary claims) was intellectually an even more complicated period in which guoxue themes appeared within the context of sophisticated questions of modernity and culture. Nevertheless, Kuomintang support helped to foreground guoxue themes in a renewed emphasis on native culture. With the Confucian revival of these years (現代新儒學, xiandai xinruxue), guoxue possibly became more closely identified with Confucianism, which once again underlined the nativist impetus that animated guoxue.

During World War II, the Communist Party itself shaped its priorities to national liberation, and to that end proclaimed the necessity of "making Marxism Chinese" (馬克思主義的中國化, makesizhuyi de zhongguohua). Marxist historiography emphasises the social dimension of history, and any discussion of the national past had to be placed within the categories of social history. This shifted the grounds in the discussion of the national past, but it would be wrong to think that concern for guoxue questions disappeared altogether. In the late 1950s, PRC historians once again undertook the discussion of how to assimilate past legacies critically. After being

6. Cheng Gang and Cao Li, "Wenhua minzu zhuyi yu wenhua shijie zhuyi" (Cultural nationalism and cultural cosmopolitanism), in Wang Ning and Xie Xiaoyuan (ed.), Quanqiuhua yu houzhimin piping (Globalisation and postcolonial criticism), Beijing, Central Compilation and Translation Press, 1998, pp. 300321, pp. 304-305.

7. "Nativism" here is my word, borrowed from studies of kokugaku (guoxue) in Tokugawa Japan (see below), and is useful because it is more specific than "nationalism," which covers a wide variety of political and cultural positions, including those that oppose efforts to render the past relevant to the present.

8. For summary discussions of guoxue by Zhang Taiyan and Hu Shi, see the selections, "Zhi guoxuede fangfa" (Method of guoxue) and "Yanjiu guogude fangfa" (Method of researching the national past), respectively, in Hu Daojing (ed.), Guoxue dashi lun guoxue (Masters discuss guoxue), Shanghai, Eastern Publication Centre, 1998, pp. 3-16. 
interrupted by the Cultural Revolution, guoxue has once again become a matter of concern. ${ }^{(9)}$

Despite guoxue's close ideological association with nativism, however, its practitioners have been open to other kinds of learning, notably, the "Western," which has appeared to be a source of success in the modern world, just as native learning has been essential to a recognisable Chinese identity in that very same world. Maybe not all practitioners could live up to Wang Guowei's dictum (王國維) that "in learning, there is no new or old, Chinese or Western, useless or useful." (10) By the standards of their times, even the "nativists" were cosmopolitan scholars who supported the importation of "Western" learning as necessary for national survival, and combined the two kinds of learning in their scholarship. It may have been Zhang Zhidong's exhortation (張之洞) in the late 1890s of "Chinese learning for substance, Western learning for function" that initially informed the first generation of guoxue advocates, but the rapidly advancing crisis of the Qing gave it additional impetus in the fears it created of the total loss of Chinese learning. This fear has been a driving force of guoxue, reinforcing its ties to "nativism" despite the cosmopolitanism in the practise of guoxue scholars. In a fundamental sense, guoxue has been a captive of its origins.

It was in nativist guise that guoxue discourse first appeared in Chinese cultural and political discussion in the early twentieth century, as one strand in an intensifying national consciousness. As with the kindred terms guocui (國粹, national essence,) and guohun (國魂, national soul), guoxue was one of the many terms of Chinese origin that were imported into Chinese in the early twentieth century after having been recomposed and endowed with a contemporary meaning in Japanese. ${ }^{(11)}$ According to Martin Bernal, one of the earliest references to guoxue was in a proposal by Liang Qichao (梁啟超) in 1902 for the establishment of a National Studies Journal (國學報, Guoxue bao) "to preserve the national essence" in order "to nourish citizens (國民, guomin)." (12) The term gained currency with the establishment in 1905 of a Society for the Preservation of National Essence (國粹保存會, Guocui baocun hui) by a group of prominent intellectuals that included Zhang Taiyan, Liu Shipei (劉師培), Huang Jie (黃節), Deng Shi (鄧實), and the journal the society published from 1905 to 1911, the Guocui xuebao (國粹學報, The Journal of National Essence). By the time of the Republican revolution of 1911, guoxue discourse was firmly established in political consciousness.

By the time it entered Chinese political discussion, the term guoxue in its Japanese rendering, kokugaku (國學), already had a history of over two centuries in political and historical discussion. Kokugaku had been born out of critiques of the Tokugawa (德川幕府, 1603-1897) crisis of the late seventeenth century, and reached its height in the late eighteenth and early nineteenth centuries, supplying the Meiji Restoration (明治維新) of 1868 with some of its slogans if not aspects of its ideology. Its target, ironically, was neo-Confucianism, which was compromised in the eyes of its critics in its service as the legitimating basis of the Bakufu (幕府), and appeared now as a foreign intrusion that long had distorted the Japanese polity as it had existed before the arrival of the foreign ideology around a thousand years ago. Kokugaku scholars sought in pre-Confucian Japanese texts the nature of this polity, and discovered it in the special nature of the imperial institution that distinguished Japan from China. Their answer was, therefore, to return power to the emperor, and cultivate among the population the pristine values of this pure Japan of the past so as to recreate this imperial community. That was one of the fundamental goals of the Meiji Restoration. In its unfolding over a period of nearly two centuries, the politics of kokugaku changed from reform of the existing order (expressed in the Confucian concept of zhongxing, literally "middle revival through moral regeneration") to its repudiation in the name of an order that had existed in a textual and imagined past (expressed once again with a term of Zhou Dynasty origins, fugu (復古), "restoring antiquity," taken very literally in the Japanese context). The shift had significant consequences, as a distinguished historian of Tokugawa thought, Harry Harootunian, has written:

The intellectual history of this period is a transition between these two metaphors of restoration. In calling for a regeneration of the human order (chuko [中興, zhongxing]) it reminded men of the lessons of history; but a summons to restore antiquity (fukko [fugu]) liberated men from history into the understanding and flexible world of myth. A restoration of the latter kind could only mean a completely new political order, free from all those historical associations which chuko required as a condition of its success. ${ }^{(13)}$

Harootunian's statement points to the implicit radicalism of kokugaku discourse, which in its desire to restore an ancient order had to repudiate the history that intervened between that order and the present. The liberation of history also enabled the re-imagining and re-invention of the past to be restored. Similar to the idea of revolution in later years, kokugaku restorationism demanded release from history. Unlike the idea of revolution, which justified this demand in the name of an imagined future, kokugaku discourse rested its case on an imagined past.

During the Tokugawa period, these arguments served to assert a native Japanese identity against the Confucianisation of Japan, and politically strengthened the case for restoring power to the Emperor, who had been relegated to the background of the Tokugawa order as a "principle" of politics. Following the Meiji Restoration, when the symbolic restoration of power to the emperor was accompanied by the reconceptualisation of Japan as a nation, kokugaku discourse turned to the articulation of Japanese uniqueness and autonomy in the creation of a modern civilisation embodied by the nation. While competing visions of Japan led to differences among kokugaku writers, the discourse presupposed a unique Japanese cultural identity, more often than not discovered in literature (especially

9. It is important to underline here that for the post-1949 period, my references are strictly to the People's Republic of China. These studies continued in Taiwan, Hong Kong, and even in the US and Europe, under the guise of "sinology."

10. Wang Guowei, "Guoxue congkan xu"(Preface to series on guoxue), in Hu Daojing (ed.), Guoxue dashi lun guoxue, op. cit., pp. 41-44. While most prominent guoxue scholars were adepts at both kinds of learning, guoxue in its emergence was partly a response to an increasingly widespread feeling after the abolition of the examination system in 1905 that the old Chinese learning was useless.

11. Zheng Shiqu, Wan Qing guocui pai: Wenhua sixiang yanjiu (The national essence group of late Qing: Study of culture and thought), Beijing, Beijing Shifan Daxue chubanshe, 1997, pp. 109-117.

12. Bernal, "Liu Shih-p'ei and National Essence," in Charlotte Furth (ed.), The Limits of Change: Essays on Conservative Alternatives if Republican China, Cambridge, MA, Harvard University Press, 1976, pp. 90112, p. 103.

13. Harry Harootunian, Toward Restoration: The Growth of Political Consciousness in Tokugawa Japan, Berkeley, CA, University of California Press, 1970, p. 11. The shift that Harootunian describes also took place during the Qing, between the Tongzhi Restoration of the 1860s to save the dynasty, which its protagonists conceptualised as zhongxing, and the radical nativist departures of the last years of the Qing, which found expression in fugu, signifying the repudiation of the Dynasty in the name of a more transcendent political entity, now envisioned as "China/Zhongguo." The shift is crucial, because it necessitated a new basis to endow the new political construct with reality. In Japan, the shift in conception justified the transfer of legitimacy from the Shogun to the Emperor, as the imperial lineage came to stand for Japan. In the case of the Qing, the problem was more complicated, as the shift was to a new conceptual entity brought from the outside, the nation. What then became essential was a "national essence" to account for the nation. This was the Euromodern guoxue project. The persistence of this questioning may also account for the refusal of guoxue to go away, despite a century of criticism and even suppression. 
language), religion (神道, Shinto), and even an intangible and invisible Japanese emotional make-up, which also accounted for the unique emperor-centred political system. ${ }^{(14)}$ It was also burdened with the task of elucidating a Japanese national essence (kokusai [guocuil) that went back to the beginnings of time and was essential to fostering national consciousness and patriotism. Despite its new departures within a context of nationalism that drew much of its grammar from the inspiration of Euromodernity, Meiji kokugaku discourse drew upon its Tokugawa antecedent to demonstrate that "the rise of the Meiji state was....the result of nationalism, rather than nationalism as the product of the nation-state." (15)

Kokugaku "central to discussions of Japan" from the 1890s was conjoined in these years to kokusui, which also gained currency from the 1880 s in reaction to the seeming flooding of Japan by "Western" values and commodities. ${ }^{(16)}$ The timing was quite fortuitous where guoxue discourse is concerned. These were years in which the crisis of the Qing dynasty intensified an emergent national consciousness, and fears of national/cultural/racial extinction gripped a transitional generation of intellectuals, mostly products of the imperial examination system but living in a post-examination (1905) world. ${ }^{(17)}$ They were also years in which Qing intellectuals became familiar with Meiji Japan, and came to see it as a model of modernisation despite its imperialism in East Asia. The idea of a Japan that had modernised without giving up its essence no doubt impressed some of those intellectuals. One contributor to Guocui xuebao wrote that "as a country's spirit lies in its national essence," whether or not guocui existed determined a country's existence. And guocui itself was nourished through its study. Through the slogan of "revere the Emperor and oppose the foreigner" (尊王攘夷, zunwang rangyi, or 尊皇攘夷, sonno joi), the Japanese had been able to summon the Yamato (大和) spirit (or 魂, hun, soul) to mobilise the people, and now enjoyed its rewards. ${ }^{(18)}$

There was much in common in the basic assumptions of kokugaku discourse and discussions of guoxue in the decade before 1911. Most important was the advocacy of return to a past that embodied the national essence. Japanese thinkers located it in the pre-Confucian origin of the imperial line. Chinese thinkers of the late Qing located the national essence in the late Zhou period, which had witnessed the flourishing of Chinese learning (at least it was becoming Chinese, rather than Zhou, by this period). Indeed, as Kang Youwei (康有為) had done with reference to Confucianism in the 1890s, guocui writers viewed post-Qin thought as a distortion of Zhou learning because of its service to imperial rule, which itself had been contaminated by repeated foreign conquest of China. The latter was "ruler-learning" (君學, junxue), not "national learning" (guoxue). (19) The proper model for social and political organisation was to be found in preImperial texts of the Zhou dynasty.

This accorded well with the politics of guocui writers who were involved in the anti-Qing revolutionary movement. It also reaffirmed the importance of intellectuals in society as the guardians of texts and, by implication, of the national essence. As in the case of the kokugaku writers in Japan, arguments for reviving antiquity had radical consequences in allowing for the imagination of political order free from the constraints of lived history. If this was conservatism, it was a conservatism that reaffirmed the necessity of radical change even as it argued for the fundamental importance of the distant past to contemporary action - "revolution as restoration" (or the reverse), as a recent study has put it. (20) Guocui xuebao writers were not particularly averse even to changing the "national learning" of which they were guardians, as they believed that a "renaissance" much like the European Renaissance was necessary in order for ancient learning to serve the needs of the present. Indeed, writers for Guocui xuebao were themselves heavily influenced by intellectual currents from Europe. Their interpretations of the Chinese past drew heavily on the inspiration of contemporary theories of progress and social evolution, social (especially gender) egalitarianism, and Jean-Jacques Rousseau's ideas of social contract. (21) It may not be too surprising that one of them, Liu Shipei, would be the guiding light of Chinese anarchists in Tokyo after 1907. There was some resonance between the guocui group's rejection of "ruler-knowledge" and Liu's discovery of anarchism in the Chinese past. (22)

Guoxue in the late Qing context had two tasks. The first was to rescue true learning (and hence the "national essence") from its distortion under imperial rule, especially foreign imperial despotism, which was directed against the ruling dynasty. Second was to make sure that as new learning was introduced to China from the "West," it remained subservient to the ethical demands of "national learning" that guaranteed the preservation of a Chinese essence. The introductory essay to the journal by Huang Jie stated that the preservation of guoxue was essential to national independence; just as it was possible for a nation to be enslaved by another, it was also possible to become a slave-in-learning (學奴, xuenu), which would also doom the possibility of national independence. ${ }^{(23)}$ Another author, $\mathrm{Xu}$ Shouwei, slightly modifying Zhang Zhidong's famous dictum of "Chinese learning for substance (ti), Western learning for function (yong)," stated that "guocui was the study of spirit (精神, jingshen), Europeanisation (歐化, Ouhua) was the study of form." (24) The same author stated in another essay that each nation had its own "national spirit" (or soul, hun), and the ultimate task of guoxue in China was the preservation of this soul, the establishment of which went back to the Yellow Emperor (黃帝). Though Guocui xuebao authors were ambivalent toward Confucianism because of its entanglement in "ruler's learning," this author also described Confucius as the model practitioner of guoxue. (25)

14. For a comprehensive discussion of kokugaku, see, Harry Harootunian, Things Seen and Unseen: Discourse and Ideology in Tokugawa Nativism, Chicago, The University of Chicago Press, 1988.

15. Susan L. Burns, Before the Nation: Kokugaku and the Imagining of Community, Durham, NC, Duke University Press, 2003, p. 225. See Chapter 7 for Burns' discussion of kokugaku following the Meiji Restoration of 1868

16. Ibid., p. 189. See also Bernal, "Liu Shih-p'ei and National Essence," op. cit., pp. 101-104.

17. Chang Hao, Chinese Intellectuals in Crisis: Search for Order and Meaning, Berkeley, CA, University of California Press, 1987; and Rebecca A. Karl, Staging the World: Chinese Nationalism at the Turn of the Twentieth Century, Durham, NC, Duke University Press, 2002.

18. Xu Shouwei, "Lun guocui wuzu yu Ouhua" (National essence is not an obstacle to Europeanisation), in Zhang Nan and Wang Zhiren (ed.), Xinhai Geming qian shi nianjian Shilun Xuanji (Selections from contemporary essays of the decade before the 1911 Revolution, hereafter XCSX), vol. 2, part I, Beijing, Sanlian, 1963, pp. 52-56. Original in Guocui xuebao, no. 7, August 1905.

19. Deng Shi, "Guoxue wuyong bian" (Refuting the uselessness of guoxue), in ibid., vol. 2, part II, pp. 632635 , originally published in Guocui xuebao, no. 30 (June 1907). Deng argues that what is useless is not guoxue, which had been suppressed during the imperial period, but "ruler's learning." Guoxue, on the other hand, has many contemporary uses.

20. Tze-ki Hon, "Revolution as Restoration: Meanings of 'National Essence' and 'National Learning' in Guocui xuebao," unpublished paper presented at the conference "The Writing of History in 20th Century East Asia: Between Linear Time and the Reproduction of National Consciousness," Leiden University, 4-7 June 2007. I am grateful to Prof. Hon for sharing his paper with me.

21. Zheng Shiqu, Wan Qing Guocui pai yanjiu, op. cit., chapters 3 and 6 .

22. Arif Dirlik, Anarchism in the Chinese Revolution, Berkeley, CA, University of California Press, 1991, especially chapter 3, and Peter Zarrow, Anarchism and Chinese Political Culture, New York, Columbia University Press, 1990.

23. Huang Jie, "Guocui xuebao shu" (On The Journal of National Essence), in XCSX, vol. 2, part I, pp. 4245, pp. 44-45. Originally published in Guocui xuebao, no. 1, February 1905.

24. Xu, "Lun guocui wuzu yu Ouhua," op. cit., p. 55.

25. Xu Shouwei, "Du Guocui xuebao ganyan" (Feelings on Reading The Journal of National Essence), in XCSX, vol. 1, part II, pp. 45-51, p. 49. 
In my references in this discussion to Guocui xuebao authors, I do not mean to suggest that these authors were all of one mind, or that discussions of guoxue constituted a unified, homogeneous discourse. Rather, my goal is to identify certain assumptions that these authors shared that gave them something of a common intellectual and political identity. It is also important to note that while Chinese authors were familiar with kokugaku discourse, and shared with it a common language, that was by no means the only discourse they drew upon for inspiration, as the discussions freely referred to other instances of national discourse and national well-being from ancient Rome to contemporary Italy, from the Renaissance in Europe to the Monroe Doctrine in the United States (as its "soul"). (26)

It should be evident from this brief summarisation that guoxue discourse was not only or primarily about learning. Guoxue as an intellectual field was the product of an emergent national consciousness of the late Qing, and the learning it advocated was intended to define and preserve a Chinese national identity. Since guoxue writers repudiated the actual, living Chinese identity that was the legacy of history, they assumed responsibility for constructing such an identity. The identity "discovered" in ancient texts was inevitably an identity invented in the present, since those texts lent themselves to different readings and were to undergo a further transformation in a "renaissance" rendering them relevant to the present.

In other words, guoxue in its emergence was shaped by the nativist paradigm demanding that native learning, as imbedded in the texts and individual exemplars of antiquity, serve as the foundation for, and a guardian over, the learning that was necessary to establishing a modern nation. It was also nativist in its identification of China with the Han nationality. Guoxue from its origins meant something along the lines of "Han national studies," putting the emphasis on the ethno-national rather than the state sense of the word "guo." Whatever purpose it may have served in the cause of Han nationalism, the identification was not necessarily positive in its consequences for native learning. What earlier had been "the" learning was now transformed into one learning among others, which needed to be defended and preserved because of its function in defining national identity, but for the same reason was restricted in appeal and relevance by its national belonging.

Guoxue may be viewed from a global perspective as one response among others to the contradictions created by nationalism under the hegemonic circumstances of Euromodernity. Establishing a nation and avoiding extinction (as Late Qing intellectuals saw it) required wholesale importation of EuroAmerican learning, and the transformation of native institutions to respond to the demands of nationalism. But this very requirement immediately raised the question of what the nation itself might be if society was to be remade in the image of models from the outside. The society as it existed offered no answers, as it was viewed widely as the problem requiring the solution. It made some sense, at least from certain perspectives, to find the answer in some imagined antiquity that necessarily rejected the history that had brought about the present, but still provided some connection with the past. It is tempting to observe, indeed, that the contradiction was resolved in this case through the "sinicisation" (中國化, Zhongguohua) of the ancient past. The solution obviously had parallels in Japanese kokugaku, which played a direct part in the Chinese formulation by providing a neighbourly example as well as a new political language. But parallels may be found further afield in the Slavophile responses to nation-building in nineteenth century Russia, the re-writing of history in twentieth century Turkey, the return to a pre-Ot- toman past in Arab nationalist historiography, or the search in Indian historiography for an authentic native past in pre-Mughal times. Others could be added to the list. Suffice it to say that in all these instances, the search for a modern national identity in the textual traditions of remote antiquity has been driven by an urge to overcome entrapment between "the West" and the immediate past held accountable for the predicament of the nation. (27)

While the content of guoxue has undergone significant transformation over the past century, initial identification with a national essence or a hallmark of national identity has remained its defining feature. New Culture radicals rejected important aspects of the past that National Essentialists had sanctified, but their own version of guoxue underlined the importance of the past to the contemporary project of modernity. A "scientific" understanding of the past was necessary as the foundation for a nation of intelligent citizens. Their cosmopolitanism was intended not to negate the nation but to establish it on firmer modern grounds. The "Reorganisation of the nation's past" (整理國故, zhengli guogu), identified with the names of $\mathrm{Hu}$ Shi and the iconoclastic historian $\mathrm{Gu}$ Jiegang (顧頴剛, 1893-1980), did not merely negate the inherited legacy. More importantly, the very historiographical issues raised in the questioning of the past opened up new horizons in the understanding of the nation and what, therefore, should be the proper content of guoxue. In his pursuit of conflicting representations of the past, imbedded in different versions of past legends, a historian such as $\mathrm{Gu}$ achieved a new understanding of China's ethnic and cultural complexity and the need, therefore, to question the very idea of "China" (Zhongguo) inherited from the past. ${ }^{(28)} \mathrm{Gu}$ was not a Marxist, but he shared with the Marxists a conviction gathering strength in the 1920s that history proper needed to be grounded in society. Over the next decade, the Marxist turn in Chinese historiography called for research into Chinese society, its social formations, and its ideological productions. Marxist historians suffered from an unquestioning theoretical and conceptual universalism, but there is little question as to the significance of the issues they brought into Chinese history and therefore into guoxue.

The historicisation of the past would negate the central idea of a history-less national essence that justified guoxue discourse. But historicisation also opened up new locations of culture, or "other possible Chinas," that challenged the boundaries of guoxue. Individuals whose scholarly career had preceded and in part shaped the May Fourth period, and who would leave a long-lasting influence on guoxue - the "four great tutors," Liang Qichao, Wang Guowei, Chen Yinke (陳寅恪), Zhao Yuanren

26. Ibid.

27. Rather than "cultural conservatism," guoxue, as well as similar undertakings in other societies, may be described more accurately as instances of "cultural nationalism," as they were anything but conservative in their demands for change. For interpretations that stress the conservatism of guoxue, see Martin Bernal, "Liu Shih-p'ei and National Essence," op. cit., and Laurence A. Schneider, "National Essence and the New Intelligentsia," in Charlotte Furth (ed.), The Limits of Change: Essays on Conservative Alternatives in Republican China, Cambridge, MA, Harvard University Press, 1976, pp. 57-89. Most of the essays in this volume used the term conservative with reference to culture, as "cultural conservatism," in order to overcome the difficulty that most individuals and groups described as conservative were also political radicals. A good discussion of cultural nationalism, with reference to Japan, is to be found in Kosaku Yoshino, Cultural Nationalism in Contemporary Japan: A Sociological Enquiry, London, Routledge, 1992.

28. See Gu's own account of his intellectual itinerary in his preface to Gushi bian (Symposium on ancient history), "Autobiography of a Chinese Historian," tr. by Arthur W. Hummel, Taipei, Cheng-wen Publishing Co, 1966. See also, Laurence Schneider, Ku Chieh-kang and China's New History: Nationalism and the Quest for Alternative Tradition, Berkeley, CA, University of California Press, 1971, and, Hon Tze-ki's important article, "Ethnic and Cultural Pluralism: Gu Jiegang's Vision of a New China in his Studies of Ancient History," Modern China, vol. 22, no. 3, July 1996, pp. 315-359. 
(趙元任) (29) - were not only adept at ancient texts, but in their scholarly practise addressed issues of both China's historical formation within a larger world context and the complexities of Chinese society. Others sought to bring together Chinese ancient civilisation and the civilisation of ancient Greece, making them classicists rather than guoxue scholars. But the overall trend was increasingly to locate Chinese identity in historical and social processes that overflowed the boundaries of historical China, rather than in textual traditions that were open to conflicting interpretations.

This tendency continued into the 1930s, but within the context of a newly established revolutionary government that nevertheless sought legitimation in the revival of native values. Kuomintang rule, following the revolutionary upheaval of the 1920s that had brought it into power and against continued Communist challenge, provided fertile grounds for nativist ideas of order. The Kuomintang blamed these phenomena (as putative products of liberalism and Marxism) on cultural degeneration by ideas imported from abroad, and sought an antidote to them in native values and traditions. One significant consequence was to establish once again values that pointed to the "essence" of being Chinese. The answer was found in Confucian values, as established by Sun Yat-sen (孫中山). The first two generations of guoxue scholars had stressed the importance of thinkers of the late Zhou Dynasty other than Confucius, who was suspect because of association of the Confucian tradition with state despotism. And sure enough, when Yuan Shikai (袁世凱) briefly restored the monarchy in 1916, Confucianism was revived, but now as state religion. The New Culture Movement, of course, made Confucius into the chief culprit for the downfall of Chinese society. The 1930s witnessed the reversal of this trend, when the Kuomintang leadership invented its own version of Sunist Confucianism, and subsequently made Confucius into a national icon. The Kuomintang turnabout encouraged the classics reading (讀經, dujing) movement, which had originated in response to declining interest in the classics following the abolition of the state examination system in 1905. More important was the restoration of Confucian celebrations and ceremonies, if under the national flag, and supervision of the political ideology established by Sun Yat-sen. Ironically, while deploying Confucianism as legitimation, the state was reluctant to pay for the upkeep of Confucian temples across the country. ${ }^{(30)}$

State patronage of Confucianism in the 1930s no doubt contributed significantly to the increasing identification of national essence, and therefore guoxue, with Confucianism, especially at the popular, public level. So did the revitalisation of Confucian thinking out of the dialogue between Chinese philosophers and "Western" philosophy, or at least the stimulus from the latter, which would come to be labelled "new Confucianism" in subsequent years. Their readings of Confucianism as philosophy and Chinese cultural endowment animate discussion to this day, and have played a major part in the most recent revival of Confucianism since the late 1970s, especially among intellectuals but extending to the general public as well. A 1958 declaration (為中國文化敬告世界人士宣言, wei Zhongguo wenhua jinggao shijie renshi xuanyan) by this new generation of philosophers made Confucian values into formative constituents of Chinese national identity and the bulwark of Chinese society - cultural DNA, so to speak. At the same time, the declaration tacitly acknowledged the retreat of Confucian values into a more restricted ethical/religious realm in its recognition of the necessity of democracy and science and technology as conditions of modern existence. This seeming de-politicisation of Confu- cianism did not preclude, needless to say, state intervention in its propagation. ${ }^{(31)}$

The revitalisation of Confucianism in the 1930s accompanied (and perhaps benefited from) a general preoccupation, cutting across political divisions, with making things Chinese (中國化, Zhongguohua). The idea is associated most closely with Mao Zedong's "making Marxism Chinese" (馬克思 主義的中國化, Makesi zhuyide Zhongguohua), which sought to translate Marxism into not only a Chinese but also a popular Chinese idiom. But it was also important in academia in calls for "making Chinese" the disciplines that were only then in the process of being introduced into the universities. It was present in the calls for a "third culture" (第三種文化, di san zhong wenhua) that, as with the idea of Zhongguohua in general, presupposed a "national character in learning." (32) This, of course, also further deepened the question of what constituted "Chineseness." (33)

These issues of the 1930s, much more than those of the May Fourth period, set the stage for discussions of Chineseness, Confucianism, and guoxue since the 1980s. There were discussions earlier in the late 1950s, no doubt, but the adverse political implications of guoxue rendered it politically undesirable and intellectually suspect. The insistent historicization of the past, this time a Marxist historicization, moreover, deprived the subject-matter of guoxue of all but historical significance. The dehistoricisation of the past was arguably a precondition of the re-emergence of the ideas associated with guoxue since the 1980s.

Indeed, a historical perspective on guoxue suggests that in addition to the two paradigms (primarily spatial) informed by nativism and cosmopolitanism, our understanding would benefit from recognition of historicism and essentialism as two further paradigmatic dimensions. The interplay of these paradigms opens up the possibility of diverse understandings of guoxue, from exclusive understandings that at the extreme restrict it to Confucianism, or maybe Daoism and Confucianism, as quintessentially Chinese philosophies and value-systems, to open-ended understandings as an account of the historical formation of Chinese society, with its own changing historical characteristics.

This breadth of coverage, with all the intellectual and ideological differences it contains, may have been one reason for the difficulties guoxue faced as a realm of critical knowledge, and possibly encouraged its identification with issues of national essence, which are driven more by conviction (and ideological work by the state and intellectual elite) than by evidence of the spatial

29. Liang Qichao (1873-1929) was one of the foremost and seminal intellectuals, journalists, and scholars of the twentieth century, responsible early on for introducing into Chinese thought new ideas from Europe, the US, and Japan. Wang Guowei (1877-1927) was a philosopher, philologist, literary historian, and a specialist on the German philosopher Arthur Schopenhauer (1788-1860), whose philosophy he deployed in his historical analyses. Chen Yinque (or Yinke) (1890-1969) was a historian trained in Tokyo, Berlin, Zurich, and Paris who was notable for his work on the Central Asian connections in Sui (589618) and Tang (618-905) histories. Zhao Yuanren (1892-1982) was a linguist trained at Cornell and Harvard universities, a one-time president of the American Linguistic Society, and professor at the University of California-Berkeley. These four distinguished intellectuals/scholars were remarkable for their global approach to Chinese studies. They came together briefly in the 1920s in the short-lived Institute for Chinese Studies (guoxue yuan) at Tsinghua University. Their work provides a model that has been adopted by the recently (re)-established Academy of Chinese Learning at Tsinghua (清華國學研究院, Qinghua guoxue yanjiuyuan).

30. For a recent discussion, see, Guannan Li, "Culture, Revolution and Modernity: The Guomindang's Ideology and Enterprise of Reviving China, 1927-1937," PhD Dissertation, Department of History, The University of Oregon, Eugene, OR, 2009, especially chapter 7, "Managing Confucianism."

31. For a sharply analytical and historical discussion, see the Introduction and Chapter One, both by Makeham, in John Makeham (ed.), New Confucianism: A Critical Examination, New York, Palgrave MacMillan, 2003.

32. Ji Wenfu, "Mantan xueshu Zhongguohua wenti" (Broad Discussion of the question of making learning Chinese), in Hu, Guoxue dashi, op. cit., pp. 109-119, p.111

33. Ibid. 
and temporal homogeneity of Chinese people around the world. Chineseness, the product of history, is rendered in the essentialist perspective into the producer of history. Likewise, guoxue, a product of modern national consciousness, is made into its bedrock to testify to the antiquity of the nation.

It is possible, however, that guoxue as a realm of learning also suffered from the reorganisation of learning in the process of building a higher education system after Euromodern models. For one thing, the appropriation of guoxue for nationalism also made it into merely a "national" form of learning, the property of one nation that is irrelevant to others. As I noted above, what had been "the" learning in the past was rendered into one learning among others with only marginal claims in an educational system that was presumably founded upon universalist assumptions. In such a context, guoxue itself becomes subject to the disciplinary requirements of modern academia. According to Tze-ki Hon, the prominent intellectual (and later anarchist) Liu Shipei in one of his contributions to Guocui xuebao "examined more than a dozen types of learning that supposedly appeared in Pre-Qin China, including psychology, ethics, logic, sociology, religion, law, mathematics, military education, natural science and fine arts." (34) In ensuing years, with the establishment of the modern disciplines in Chinese universities, guoxue itself, when it existed as an academic unit, existed as one among many others that studied the Chinese past, now with the authority of modern science and academic division of labour (for example, the short-lived Tsinghua Institute of Chinese Classics, now the model for Humanities at the University). ${ }^{(35)}$ One prominent historian educated abroad went so far as to declare that if the past was to be understood, guoxue should be abolished. ${ }^{(36)}$ In other words, in addition to being ideologically suspect in the eyes of progressives in academia, guoxue also suffered from a diffuseness of subject-matter (or, conversely, insistence on a holistic understanding of it) that clashed with the disciplinary requirements of the Euromodern organisation of learning.

Guoxue also retreated with advances in the knowledge of the past brought about by new disciplines, including the very practise of guoxue. Archaeology was one discipline with revolutionary implications for rewriting the past. A wilful resistance to archaeological evidence in the name of the sanctity of the written classics, as in the case of Zhang Taiyan, could not be sustained except as the eccentricity of a brilliant maverick. (37) But the diffusion of guoxue concerns across academic disciplines also meant that where guoxue had a disciplinary identity, the identity was conditioned by methodological boundaries of philological and textual research. From an intellectual perspective, this may be similar to the transformation of sinology (or other Orientalisms) in EuroAmerican universities from the analysis of all aspects of entire civilisations to narrow (and largely marginalised) purveyors of philological and textual research. Indeed, some scholars have described guoxue as a Chinese version of foreign sinology, richer than the latter by virtue of national affinity to the past, but otherwise relegated to a similarly restricted domain. Aside from problems of ideology, intellectual boundaries, and methods, recognition of the disciplinary predicament of guoxue is important in assessing its current possibilities and the challenges it faces in a new context of global modernity.

\section{Guoxue/global modernity}

Cheng Gang and Cao Li have observed shrewdly that there has been a shift in recent years in both the advocacy of guoxue and its intellectual environment. They have argued that over the years, guoxue has been nour- ished by sense of "lack" - a sense that China lacked the integrated wholeness of Western society, as well as a feeling that Chinese culture lacks a centre, or that the centre is perpetually receding. ${ }^{(38)}$ This sense of lack has been replaced since the 1990s with a newfound sense of success in modernity. It is currently a sense of confidence that drives the guoxue revival.

The international environment likewise has changed. Postmodernism has called into question the temporalities of modernisation, so that there is now no clear distinction between what is conservative or progressive. It has also encouraged a relativism that enables the recognition of value in different thought and value systems, and rejects imposing on weaker societies the value standards of the powerful. The importation of these ideas to China has also enabled renewed confidence in the assertion of Chinese difference. ${ }^{(39)}$

These are important insights. And yet, we must remember not to confuse intellectuals' postmodernism with the universal or general acceptance of relativistic arguments. These years have also seen the hardening of cultural boundaries in the upsurge of cultural nationalism that inspired Huntington. The increased recognition of difference has liberated many from unipolar modes of thinking, but it has also brought increased friction, as ethnic and cultural boundaries are hardened with the reification of culture and assumptions of homogeneity within national or ethnic boundaries - by liberal multiculturalism on the one side, and an elevated ethnic, racial, and religious consciousness among more conservative populations. The celebration of difference, accompanied by deadly conflict over difference on a daily basis, is a pervasive feature of global modernity. Difference is not just an intellectual question; it is also political and therefore entangled in questions of power and hegemony.

I think this context is of necessity the point of departure for any contemporary consideration of the domain and tasks of guoxue. Before I state my understanding, let me make two observations that underlie my understanding. What is not in question is whether or not guoxue is a legitimate public/intellectual and academic domain. That question has already been answered by the enthusiastic response in both academia and among the public to the call of guoxue. While the advocacy of guoxue raises both cultural and political issues that call for critical attention, there is obviously nothing wrong or automatically regressive in the appreciation of past legacies in China or elsewhere; nor is there any self-evident justification for political policing of what legacies may be admissible - unless, of course, we wish to advocate thought control of one kind or another.

It does not follow, however, that guoxue is therefore a universal, or the most fundamental, cultural force in contemporary Chinese lives, which are caught up in the material and cultural commodity circulation of global capitalism. Guoxue may currently serve a number of needs, from the political to the cultural, spiritual, and intellectual. But beyond these needs is the very status of guoxue itself in a new context of globalised commodity

34. Tze-ki Hon, "National Essence, National Learning, and Culture: Historical Writings in Guocui xuebao, Xueheng and guoxue jikan," Historiography East and West, vol. 1, no. 2, 2003, pp. 244-286, pp. 249250.

35. I am grateful to John Makeham for pointing out that guoxue was never made into a department.

36. He Bingsong, "Lun suowei 'guoxue'"' (On so-called 'guoxue), in Hu, Guoxue dashi lun Guoxue, op. cit., pp. 60-70.

37. Guo Zhanbo, Jin wushinian Zhongguo sixiang shi (Chinese thought of the last 50 years), Hong Kong, Longmen Bookstore, 1935, p. 69. Zhang was famous for refusing to believe archaeological evidence over the evidence of the classics that the Colden Age of sage rulers and emperors should indeed be considered the "primitive" phase of Chinese history.

38. Cheng Gang and Cao Li, "Wenhua minzu zhuyi yu wenhua shijie zhuyi," op. cit., pp. 308-309.

39. Ibid., pp. 13-14. 
culture. Indeed, while guoxue is open to use as an antidote to the cultural commodities in global circulation, it is itself caught up in the gravitational field of the latter, not just in public but also in academic life. In other words, guoxue itself is available as a commodity for cultural consumption at many levels. This may make it more difficult to define than ever before. ${ }^{(40)}$ At the same time, it may also suggest a point of departure in sorting out the tasks of guoxue as a critical undertaking at this juncture: explaining how this situation has come about.

Critical understanding of guoxue demands a critical understanding of the history of guoxue in relation to other ways of understanding the past. It is important to understand why guoxue has been controversial over the years. As with other civilisational claims of the contemporary world - from Christian to Moslem to Hindu to proliferating indigenous claims, among many others - the resurgence of the learning associated with guoxue represents at one level a release from the hegemony of a Eurocentric modernity. The denial of a centre to modernity, however, presents its own predicament: a loss of common standards of what is and is not appropriate knowledge. The loss of a commonly shared critical standard also makes it easier to subject learning to the claims of ideology, whether of nations, classes, or other social groups. Guoxue should be a point of departure for new kinds of investigation: of its own past, as well as of emergent practices of national learning globally. The rendering of guoxue into a marker of national identity severely limits its epistemological claims by making them into functions of national identity. Guoxue needs also to explore the supranational possibilities of varieties of national learning. Those who have pushed the frontiers of guoxue in the past have done so through openness to cultural complexity within China, and to global perspectives on Chinese society - both in the scope of their investigations and in their methodological assumptions. ${ }^{(41)}$ In post-revolutionary China, the history of guoxue includes the history of the revolution, and needs to be understood in that context. It also includes national struggles with Eurocentric hegemony, which now have been replaced with the ideological multi-polarity of global modernity. That, too, is part of its constitution. ${ }^{(42)}$

Secondly, after a century of preoccupation with Euro/American hegemony, it makes sense to adopt a more global perspective on cultural comparison than that implied by Chinese/Western binarism, which also suggests that the only desirable response to Eurocentrism is Sinocentrism. Indeed, if the goal is truly to discover what may be unique to Chinese society in terms of values, comparison with the modern "West" hardly provides a sufficient basis. This preoccupation with Euro/America, in China as in other like societies, is a major force in perpetuating Eurocentrism. There is little political or academic incentive in pursuing questions of learning through comparison between societies of the South, as well as indigenous societies, but this in fact would be a major contribution of a guoxue genuinely free of Euro/American intellectual hegemony. ${ }^{(43)}$ While it may seem degrading to the more civilisation-minded to compare Confucian or Daoist ideas to the outlook of indigenous peoples, the holistic ecological outlook implicit in such ideas as tianren heyi (天人合一, unity of heaven and humans) or tian/di/ren (天地人, heaven/earth/human), deemed to be fundamental to a Chinese value-system, are ideas that are quite commonly found in indigenous philosophies. There is much of human significance to be gained from placing post-Euromodern readings of Confucian, Daoist, or Buddhist values within the context of post-Enlightenment critical indigenism that shares the common goal of revitalising holistic views of humans, society, and nature to remedy the deficiencies of advanced capital- ism and its seemingly inexorable "creative destruction" of social harmony and ecological well-being. ${ }^{(44)}$

Finally, a word about academic function. If Chinese learning has already been fragmented into disciplines, guoxue may perform an important task in formulating projects that cut across disciplinary and area divisions. This may sound like going back to older sinological models, but it is not. The role to be assumed here is not of container but of intermediary; not to dissolve the disciplines into Chinese studies but to weave Chinese studies on an ongoing basis out of disciplinary findings. The proper analogy here is

40. Hence a senior Chinese scholar of philosophy and religion at the Chinese Academy of Social Sciences, Yu Dunkang, complains that it is impossible to say what guoxue should be about, or what culture it is supposed to revive, because everyone seems to have their favourite choice; in the end, everything Chinese is guoxue. See the interview in "Guoxue yuantou" (Sources of guoxue), in Liang Chu, Guoxue fangtan: Guangming ribao guoxue zhuankan jingxuan (Conversation visits on guoxue: Selections from Guangming Daily special edition on guoxue), Beijing, Guangming Daily Publishers, 2008, pp. 105-112, p. 106. Confucianism and Daoism now also appear in Chinese societies in a self-help New Age guise. See, for example, Fu Peirong, Guoxuede tiankong (The boundless space of guoxue), Xi'an, Shaanxi Normal University Press, 2009, and most famous of all, the works of the television Confucian star, Yu Dan. The attribution of Eastern Asian economic success to the cultural legacies of Chinese, Korean, and Japanese societies, especially Confucianism, is no doubt largely responsible for the stimulation of interest in guoxue as well. Guoxue, of course, is also conceived by some as a means to promote a more ethical and socially conscious approach to business. See, Dong Zizhu, Yu qiyezhe liao Guoxue (Guoxue for entrepreneurs), Wuhan, Changjiang Arts and Literature Publishers, 2008.

41. For anthropological perspectives on how comparative and popular culture studies may contribute to guoxue, see "Laizi renleixuede shengyin"(Voices from anthropology), in Liang Chu, Guoxue fangtan, op. cit., pp. 236-250, pp. 241-242. Anthropologists and cultural studies scholars are more in the tradition of Gu Jiegang (the "new tradition," xin chuantong) in their emphases on popular culture and closer attention to non-Han ethnic groups. According to an anthropologist such as Wang Mingming, guoxue in turn may help anthropology overcome domination by concepts of European cultural origin (and hence help indigenise [bentuhua] anthropology).

42. These concerns have been expressed by Chinese scholars of an earlier generation such as Zhang Dainian and Tang Yijie, who have also stressed the importance of recent history to a post-socialist guoxue. See, Zhang Dainian, "Shuo 'guoxue,"'(On 'guoxue), in Hu, Guoxue dashi, op. cit., pp. 161-163, p. 163. See also the discussions by Tang Yijie, Ren Jiyu, et al., "Guoxue yu ershiyi shiji" (Guoxue and the twentyfirst century), in Liang Chu, Guoxue fangtan: Guangming ribao guoxue zhuankan jingxuan, op. cit., pp. 178-183. Yu Dunkang, whom I cited above for his complaints about the diffuseness of guoxue and what it is expected to revive, writes that "guoxue is culture, culture is not something on a piece of paper, but the way of life of the Chinese people, rooted deep in the traditions that live on in the hearts of the people" (p. 181).

43. The importance of inter-cultural dialogue is recognised by scholars such as Liu Dong, but it has been restricted so far mostly to "Chinese-Western" dialogue. Overcoming this binarism, and the reification of both China and the West, is a precondition for critical opening up of guoxue. For Liu Dong, see Chang Gang and Cao Li, "Wenhua minzu zhuyi yu wenhua shijie zhuyi," op. cit., pp. 315-317. Wang Mingming is one scholar who has been critical of the "progressivism" (jinbu zhuyi) that encourages comparison with the advanced and ignores the rest of the world (such as Africa). See his comments in Liang Chu, Guoxue fangtan, op. cit., p. 250.

44. To my knowledge, Tu Wei-ming is the only scholar of Confucianism who has pointed to this connection. See, Tu, "Beyond the Enlightenment Mentality," in Mary Tucker and John Berthrong, Confucianism and Ecology: The Interrelation of Heaven, Earth and Humans, Cambridge, MA, Harvard University Center for the Study of World Religions, 1998, pp. 3-21, p. 8. The philosophical existence of these values does not mean that they necessarily guide behaviour, as in the case of "the unity of heaven and humans," for instance, which is overwhelmed by the developmentalism that guides official thinking and popular sentiment - another challenge for guoxue scholarship!

45. Chinese scholars pointed to this problem of parochialisation in the 1930s as a caution against arguments to make learning Chinese. See, Ji, "Mantan xueshu Zhongguohua wenti," op. cit. There are proliferating examples of efforts to articulate Confucianism and Daoism to contemporary problems, most prominently ecological problems. See, N. J. Girardot, James Miller, and Liu Xiaogan (ed.), Daoism and Ecology, Cambridge, MA, Harvard Divinity School Center for the Study of World Religions, 2001, and, Mary Evelyn Tucker and John Berthrong (ed.), Confucianism and Ecology. For a more down-to-earth deployment of guoxue issues in contemporary intellectual discussions, see the discussion of modernity in Wang Hui, "Scientific Worldview, Culture Debates, and the Reclassification of Knowledge in Twentieth Century China," in which Wang discusses Zhang Taiyan with reference to issues of modernism and anti-modernism (Boundary 2, vol. 35, no. 2, Summer 2008, pp. 125-155). Indeed, there long has been a blurring of the inside/outside distinction in the discussion of guoxue issues, and discussions outside of the People's Republic of China (not just other Chinese societies) may well have played a part in stimulating discussions in the PRC. The case of guoxue is the latest example of the part played by the transnational circulation of ideas (Buddhist to Christian to Euromodern) in the shaping of imperial scholarship. I am grateful to Samuel Cheung for reminding me of this important point. For interesting discussions of this problem, see Zhu Weizheng, "Han learning and Western learning in the eighteenth century," in Zhu Weizheng, Coming out of the Middle Ages: Comparative Reflections on China and the West, tr. and ed. by Ruth Hayhoe, Armonk, NY, ME Sharpe, 1990, pp. 113-142; and Lionel M. Jensen, Manufacturing Confucianism: Chinese Traditions and Universal Civilization, Durham, NC, Duke University Press, 1997. Zhu's article is also noteworthy for stressing the relationship between transnational flows and the regionalising of imperial scholarship. 
with "national studies" elsewhere, which take the nation as a point of departure to inquire critically into both its internal constitution and its place in the world. This, too, requires a guoxue that is not shrunk into a marginal discipline but is in constant exchange with other disciplines - and not just the humanities. ${ }^{(45)}$

Guoxue in China faces challenges similar to those of other national/civilisational/ indigenous legacies of learning that currently demand a hearing as constituents of global modernity. Dialogue with these various legacies, including the Euro/American, is essential to assessing its own particularities among different value and knowledge systems. It is also a necessity for overcoming a parochial incarceration in nationalist ideology in favour of a more universalistic appreciation of China's contribution to the global storehouse of ideas and values. 